\title{
Impact of humidity on current parameters of solar cells
}

\author{
Erdem Cuce \\ Bayburt University, Faculty of Engineering, Mechanical Engineering Department, Dede Korkut Campus, 69000 \\ Bayburt, Turkey, erdemcuce@ bayburt.edu.tr, ORCID: 0000-0003-0150-4705 \\ Pinar Mert Cuce \\ Recep Tayyip Erdogan University, Faculty of Engineering, Energy Systems Engineering Department, Fener \\ Campus, 53100 Rize, Turkey, pinar.mertcuce@erdogan.edu.tr, ORCID: 0000-0002-6522-7092 \\ Tulin Bali \\ Karadeniz Technical University, Faculty of Engineering, Mechanical Engineering Department, 61080Trabzon, \\ Turkey, bali@ktu.edu.tr, ORCID: 0000-0003-0150-4705
}

Arrived: 08.07.2018 Accepted: 08.08.2018 Published: 30.09.2018

\begin{abstract}
In this research, impacts of relative humidity on current parameters of solar cells are investigated. An experimental methodology is considered in the research. Outdoor tests are carried out for two different cell technologies, monocrystalline (m-Si) and polycrystalline silicon solar cell (p-Si), under various humidity conditions. Current-voltage (I-V) and power-voltage (P-V) characteristics are achieved simultaneously for each sample, and the relationship between the short circuit current $\left(\mathrm{I}_{\mathrm{sc}}\right)$ and relative humidity is discussed. During the tests, cell temperature of $\mathrm{m}$-Si and $\mathrm{p}$-Si sample is measured to be in the range of 22.9-36.1 and 21.2-38.9 ${ }^{\circ} \mathrm{C}$, respectively. It is unequivocally reported in literature that current parameters are not noticeably affected by the rise in cell temperature up to $20^{\circ} \mathrm{C}$. Therefore, any deviation from the linearity between solar intensity level (G) and $\mathrm{I}_{\mathrm{sc}}$ is attributed to the impact of relative humidity. The tests repeated for low and moderate solar intensity levels $\left(257-482 \mathrm{~W} / \mathrm{m}^{2}\right)$ reveal that the linear relationship between $\mathrm{G}$ and $\mathrm{I}_{\mathrm{sc}} \mathrm{is}$ maintained for different humidity levels. In this respect, the impact of humidity level on current parameters of solar cells is found to be insignificant
\end{abstract}

Keywords: Solar cells, Parameter extraction, Solar intensity, Relative humidity, Short circuit current,

Cite this paper as: $\quad$ Cuce, E., Cuce, P.M., Bali, T., Impact of humidity on current parameters of solar cells. Journal of Energy Systems 2018; 2(3): 84-96, DOI: 10.30521/jes.441643

(C) 2018 Published by peer-reviewed open access scientific journal, JES at DergiPark (www.dergipark.go5.tr/jes) 


\section{INTRODUCTION}

There is a rising stimulation into renewable energy technologies in the world today due to growing significance of environmental issues such as ozone layer depletion, global warming and climate change [1]. Although renewable provide a wide range of solutions, it is easy to emphasise that solar energy has the greatest potential to be considered among the all alternatives to minimise the gap between fossil fuels and clean energy technologies [2]. Direct conversion of sunlight into electricity through the photovoltaic effect is in the centre of interest over the last four decades, and intensive efforts take place all over the world to improve the electrical performance figures of photovoltaic (PV) cells and modules [3]. It is well-documented in literature that thermodynamic efficiency parameters of PV modules are notably affected by cell temperature, which is usually encountered in hot and temperate climatic conditions [4]. Dramatic drop in power outputs of PV modules with increasing cell temperatures is attributed to the notable cell temperature dependency of voltage parameters [5]. It is also reported that current parameters are insignificantly dependent on cell temperature for the low and moderate solar intensity levels [6]. For maximum energy generation from PV modules, solar cell parameter extraction is of vital importance to have an understanding about the dependency of performance figures to climatic conditions. The most common climatic condition parameters which are widely analysed by researchers are solar intensity and ambient temperature [7]. There are several works in literature which aim at investigating the impacts of solar intensity [8] and cell temperature [9] on current [10] and voltage parameters [11] of solar cell and modules. Active [12] and passive cooling [13] of PV modules are also studied as well as tilt angle optimisation [14].

Enhancement of electrical performance parameters in a PV cell or module is usually performed by improving either current or voltage parameters. Current parameters can be enhanced by maximising incoming solar radiation via typical concentrators [15]. Voltage parameters are improved by using an active or passive cooling system. In most cases, passive systems are preferred since there is no additional energy consuming device in the operation [16]. In a PV cell or module, two resistors are required to be added to the Shockley's ideal diode equation to be able to represent the electrical behaviour in a realistic and reliable manner [17]. This approach is commonly known as five parameter method in literature. In this respect, current-voltage relation of a PV module can be given as follows [18]:

$$
I=I_{p h}-I_{s}\left[\exp \left(\frac{\beta}{N n}\left(V+I R_{s}\right)\right)-1\right]-G_{s h}\left(V+I R_{s}\right)
$$

In Equation 1, $\beta$ is the usual inverse thermal voltage $(\beta=\mathrm{q} / \mathrm{kT}) . \mathrm{N}$ represents the number of cells in series and $\mathrm{n}$ is the ideality factor. $\mathrm{I}_{\mathrm{ph}}$ and $\mathrm{I}_{\mathrm{s}}$ are photocurrent and diode saturation current, respectively. $R_{s}$ and $R_{s h}$ are series and shunt resistances, and $R_{s h}$ can be expressed in the shunt conductance form as $\mathrm{G}_{\mathrm{sh}}$. The resistance terms address the dissipative effects and construction defects causing parasite currents within the PV module [19]. It is reported in literature that one diode equivalent circuit model shown in Figure 1 usually gives satisfactory results as underlined by Ciulla et al. [20]. It is easy to say that Equation 1 is implicit, and cannot be solved analytically. Therefore, several numerical and experimental attempts are done to investigate the impacts of climatic and operational parameters on the electrical performance figures of PV modules. 


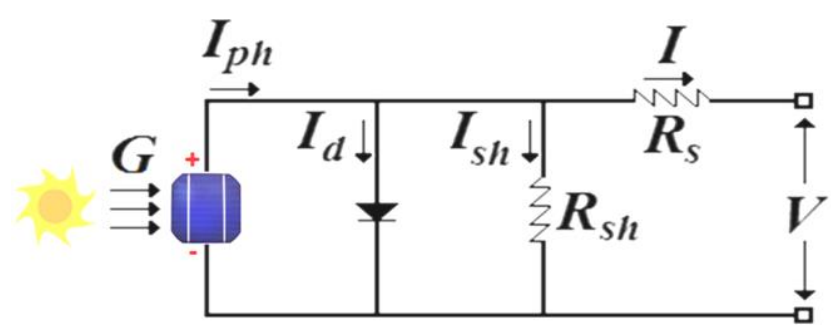

Figure 1. One-diode equivalent circuit model for a PV module [6].

It is observed from the literature that a significant number of methods is considered for the solution of implicit PV cell equation. For instance, Bouzidi et al. [21] modify the PV cell equation in the form of $V=f(I)$ instead of $I=f(V)$. Dimensionless equation coefficients $\left(\mathrm{C}_{0}, \mathrm{C}_{1}\right.$ and $\left.\mathrm{C}_{2}\right)$ are determined via the least squares method for the extraction of five parameters. Chegaar et al. [22] evaluate the effectiveness of four numerical approaches (modified analytical five-point method, vertical optimization method and their own two methods) in solar cell parameter extraction. Photocurrent, diode saturation current, series resistance, ideality factor and shunt conductance are derived from each method, and the results are found to be comparable with the experimental data. In another research, Chegaar et al. [23] propose a new technique which utilises a conductance expression. Through the nature of the methods, number of parameters in the PV cell equation reduces to four. A nonlinear least squares optimization algorithm based on the Newton model is considered to extract the said parameters. They also develop a novel technique for PV cell parameter extraction by considering an arbitrary voltage function. The accuracy of the model is justified for the measurements conducted for a silicon PV cell and module [24]. Adawi and Nuaim [25] present a method to determine series resistance of a PV cell from one single current-voltage curve. For two different solar intensity values (60 and $90 \mathrm{~W} / \mathrm{m}^{2}$ ) series resistance is determined to be 3.2980 and $3.3689 \Omega$, which is in good accordance with the reference value of $3.3 \Omega$. Radziemska and Klugmann [26] investigate the electrical performance figures of a silicon PV cell for different cell temperatures $\left(22-70{ }^{\circ} \mathrm{C}\right)$. They observe about $0.8 \%$ decrease in electrical energy output per unit temperature increase. Short circuit current is found to increase slightly with increasing cell temperature whereas open circuit voltage notable decreases. In recent years, alternative methods are also developed such as particle swarm optimization [27], genetic algorithm [28], chaotic whale optimization algorithm [29] and artificial bee colony [30].

On the contrary to the comprehensive theoretical, numerical and experimental attempts for accurate and reliable PV cell parameter extraction under different solar intensity levels and cell temperatures, it is easy to underline that there are very few works in literature to analyse the potential impacts of relative humidity on current-voltage characteristics of a PV cell or module [31]. Moreover, they said works include some contradictions among themselves. Analysing the impacts of relative humidity on PV cell performance can be conducted through two scenarios: Influence of water vapour particles on the solar intensity level and the humidity penetration to the PV cell enclosure. The second scenario is assumed to negligible within the scope of this research by considering the PV cell enclosure to be completely watertight. It is well-documented in literature that when the sunlight passes through humid air, three scenarios might take place, which are refraction, reflection and diffraction of light [31]. Humidity level is not expected to have an impact on voltage parameters as they are mainly dependent on cell temperature [32]. However, relative humidity might have an influence on incoming solar radiation, thus on the current parameters, which is the main goal of this research. Although a nonlinear relationship between solar intensity and relative humidity is already provided by Gwandu and Creasey [33], it is difficult to make a general assessment due to the limited data utilised in the analysis. Therefore, this research is carried out to analyse whether current parameters are affected by the change in relative humidity. Through the fact that relative humidity might have an impact on current parameters only, $I_{p h}$ is expected to be influenced by the change in relative humidity when a noticeable change takes place due to moisture content of air. $I_{p h}$ of a PV module at a certain cell temperature is given depending on a reference condition, which is usually standard test conditions (STCs): 


$$
I_{p h_{T}}=I_{p h_{T_{r e f}}}+\xi\left(T-T_{\text {ref }}\right)
$$

In Equation 2, $\xi$ is the temperature coefficient of $I_{p h}$, which is expected to change with relative humidity. For an easier assessment, $I_{p h}$ can be replaced with $I_{s c}$ since short circuit current can be easily determined through the terminals of PV module. In this respect, $\xi$ can be expressed as follows:

$$
\xi=\frac{I_{s c_{T}}-I_{s c} T_{r e f}}{T-T_{r e f}}
$$

\section{METHODOLOGY}

Within the scope of this research, any potential impact of relative humidity on electrical performance figures of PV modules is experimentally analysed. Since the moisture content of air has no influence on the cell temperature, voltage parameters are not expected to change for different values of relative humidity. However, relative humidity might have an impact on the incoming solar radiation, thus on the current parameters. In this research, short circuit current is taken as a reference since its behaviour with the change of solar intensity is well-documented. Through the outdoor tests carried out for different solar intensities and relative humidity values, the relationship between incoming solar radiation and short circuit current is evaluated. A linear dependency of short circuit current on solar intensity is explained with the insignificant impact of relative humidity on current parameters. The deviation from the linearity is attributed to the influence of relative humidity on current-voltage characteristics of PV modules.

\section{EXPERIMENTAL}

The tests are carried out in an open space without the shading effects. For a reliable and realistic approach, two different PV cell technologies (10 Watt m-Si PV module from Ekosolar Company and 10 Watt p-Si PV module from Alfasolar Company). The identical power output is considered for the samples for an accurate assessment. Electrical performance characteristics of each PV module provided for standard test conditions (STCs) are illustrated in Table 1.

Table 1. Electrical performance figures of PV modules at STCs [18].

\begin{tabular}{lll}
\hline 10 Watt m-Si PV module & & \\
\hline Solar intensity & $1000 \mathrm{~W} / \mathrm{m}^{2}$ & $1000 \mathrm{~W} / \mathrm{m}^{2}$ \\
Cell temperature & $25^{\circ} \mathrm{C}$ & $25^{\circ} \mathrm{C}$ \\
Open circuit voltage & $21.4 \mathrm{~V}$ & $21.6 \mathrm{~V}$ \\
Short circuit current & $0.616 \mathrm{~A}$ & $0.640 \mathrm{~A}$ \\
Maximum voltage & $17.8 \mathrm{~V}$ & $17.39 \mathrm{~V}$ \\
Maximum current & $0.560 \mathrm{~A}$ & $0.580 \mathrm{~A}$ \\
\hline
\end{tabular}




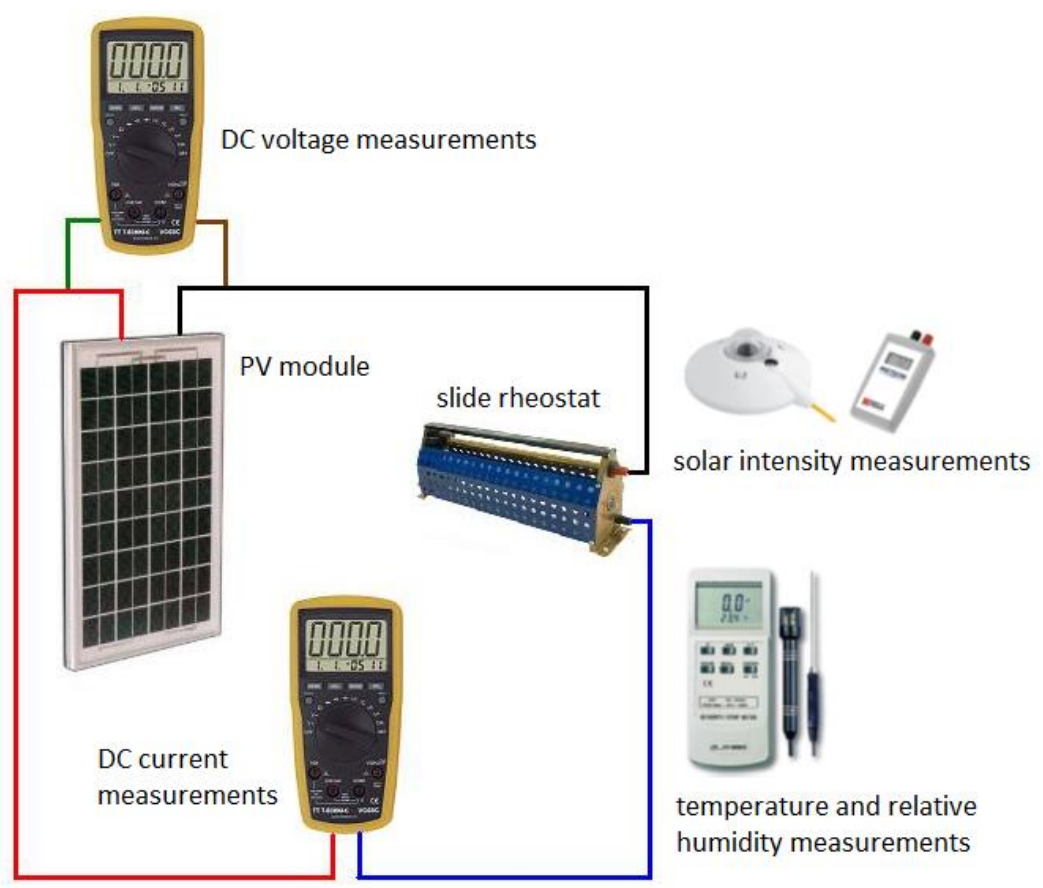

Figure 2. Schematic of the test rig for the outdoor measurements.

The tests are conducted in autumn when the change in relative humidity on daily basis is limited. Highly sensitive measurement systems are utilised in the experiments. The test rig is illustrated in Figure 2. Solar intensity values are measured via CMP 11 pyranometer from Kipp \& Zonen Company. The said sensor is capable of producing time-dependent solar intensity data with an error below $0.2 \%$, which is satisfactory. For DC voltage and current measurements, Fluke $87 \mathrm{~V}$ multimeters are utilised. DC voltage and DC current values are determined with an error of $0.05 \%$, which is completely acceptable. Outdoor air temperature and relative humidity values are measured via LUTRON HT3006 HA temperature/humidity sensor, which is very sensitive and has a very short response time. The resistance of the circuit is changed manually by a slide rheostat. Each single test takes about 15 minutes. Cell temperatures are measured by standard $\mathrm{K}$ type thermocouples. Current-voltage characteristic curves are achieved, and following the accuracy justification through the manufacturers' data reports, relative humidity dependency of PV modules are discussed. Total uncertainty of the measurement system is found to be below $1 \%$, which is acceptable. For the determination of total uncertainty, a basic method described by Holman [34] is utilised. The definition is transformed to the power output since current and voltage measurements are conducted simultaneously. The exact uncertainty value for power output measurement is calculated to be $0.0035 \%$.

$$
\delta P=\left[\left(\frac{\partial P}{\partial I} \delta I\right)^{2}+\left(\frac{\partial P}{\partial V} \delta V\right)^{2}\right]^{1 / 2}
$$

\section{RESULTS and DISCUSSION}

For m-Si PV module, five independent tests are conducted for five different test days with different climatic conditions. Current-voltage and power-voltage characteristic curves are achieved for each test. The results of the first test are depicted in Figure 3. For the first test, solar intensity is measured to be $415 \mathrm{~W} / \mathrm{m}^{2}$. Cell temperatures and ambient temperatures are determined to be 22.9 and $19.4{ }^{\circ} \mathrm{C}$, respectively. Relative humidity is found to be $61.4 \%$. 

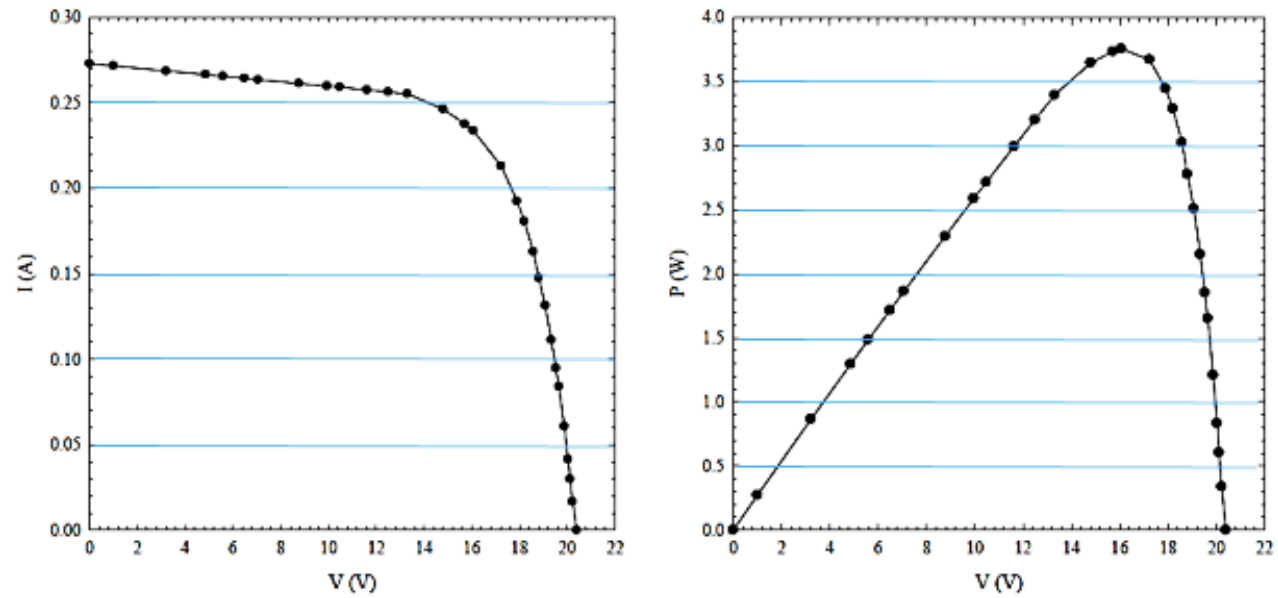

Figure 3. I-V and P-V characteristic curves of m-Si PV module from the first test: $G=415 \mathrm{~W} / \mathrm{m}^{2}, T_{c}=22.9^{\circ} \mathrm{C}$, $T_{a}=19.4^{\circ} \mathrm{C}$ and $\phi=\% 61.4$.
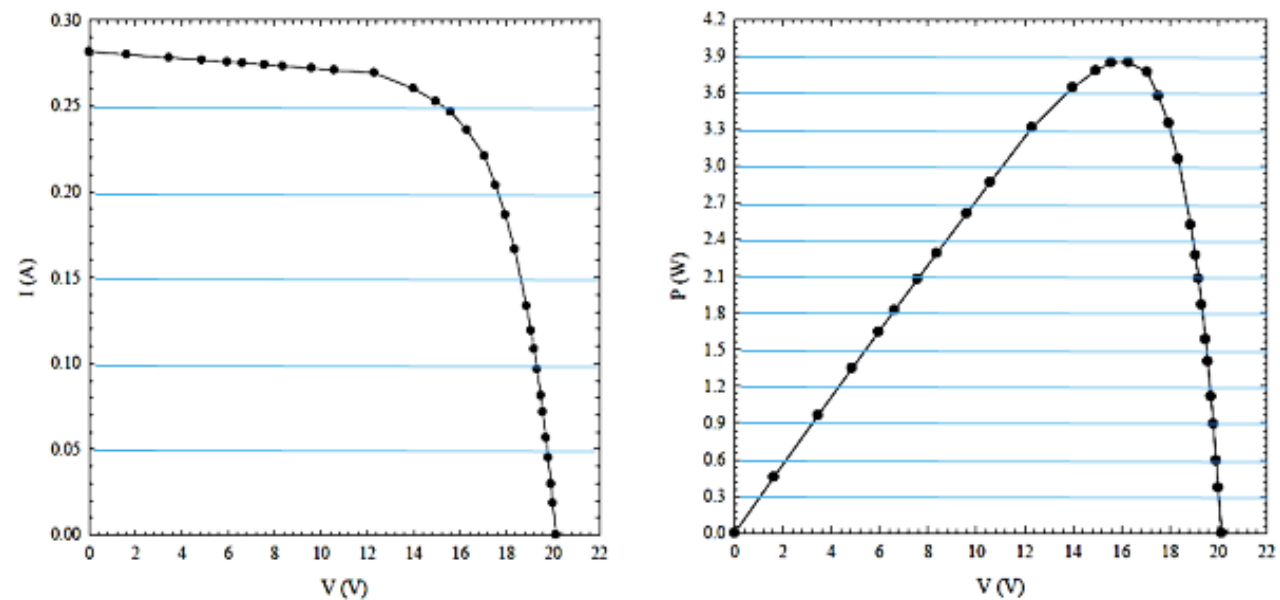

Figure 4. I-V and P-V characteristic curves of $m$-Si PV module from the second test: $G=430 \mathrm{~W} / \mathrm{m} 2, T c=24.6$ $o C, T a=20.3 o C$ and $\phi=\% 64.4$.
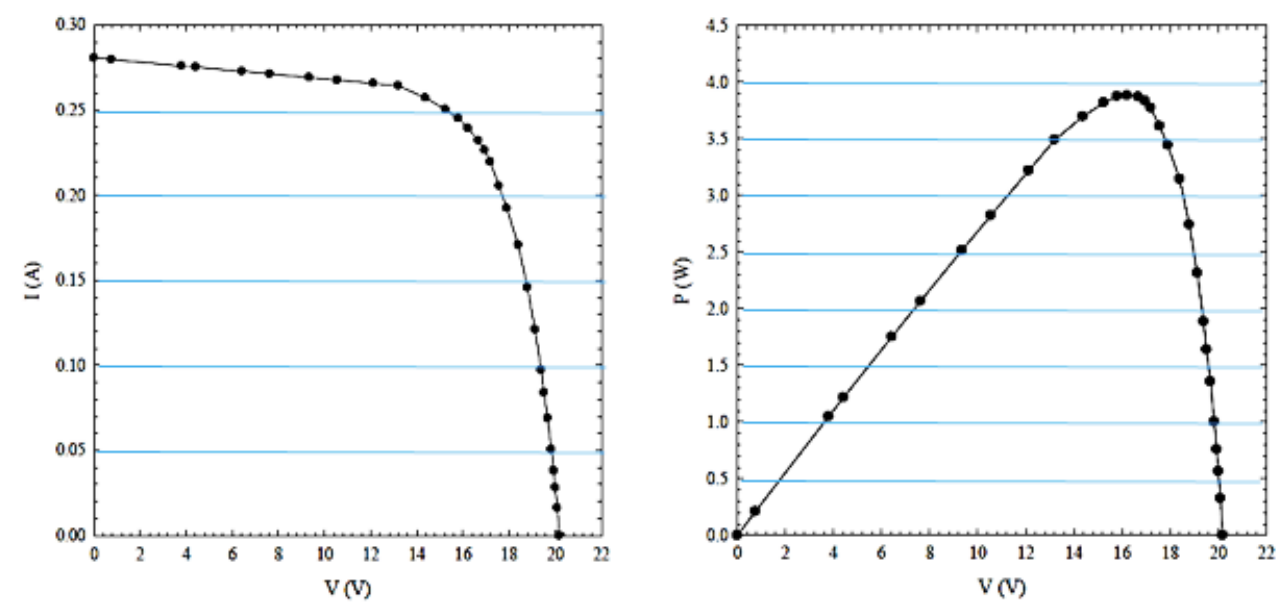

Figure 5. I-V and P-V characteristic curves of m-Si PV module from the third test: $G=432 \mathrm{~W} / \mathrm{m}^{2}, T_{c}=25.7^{\circ} \mathrm{C}$, $T_{a}=19.8^{\circ} \mathrm{C}$ and $\phi=\% 63.5$. 

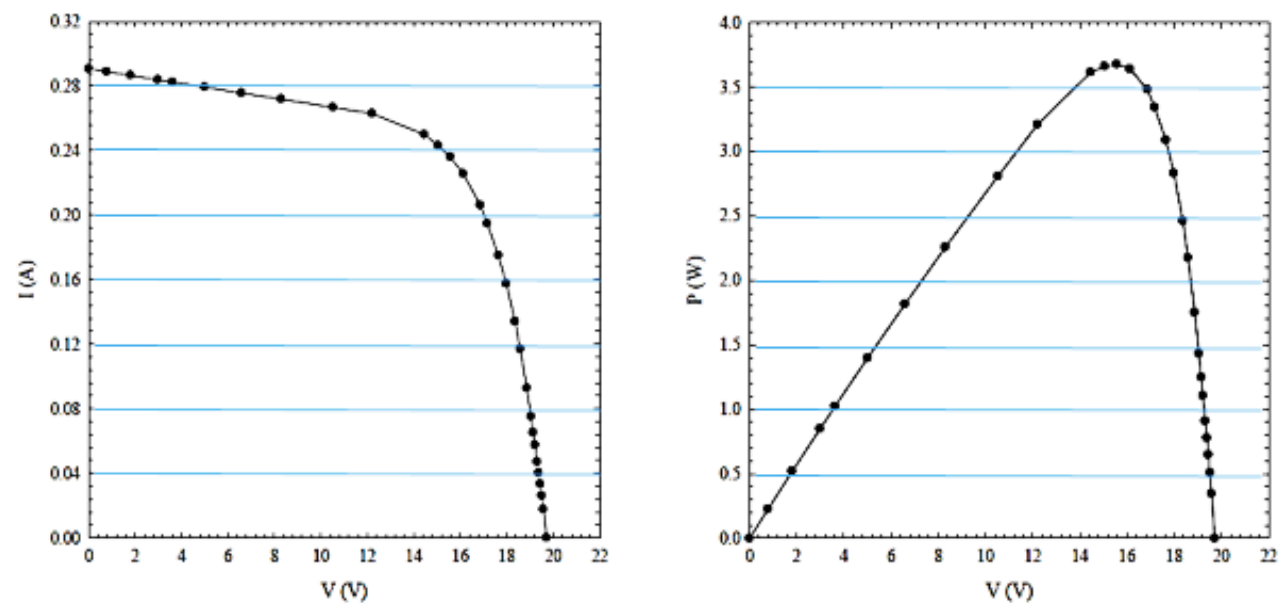

Figure 6. I-V and P-V characteristic curves of $m$-Si PV module from the fourth test: $G=450 \mathrm{~W} / \mathrm{m}^{2}, T_{c}=36.1^{\circ} \mathrm{C}$, $T_{a}=24.3^{\circ} \mathrm{C}$ and $\phi=\% 57.9$.
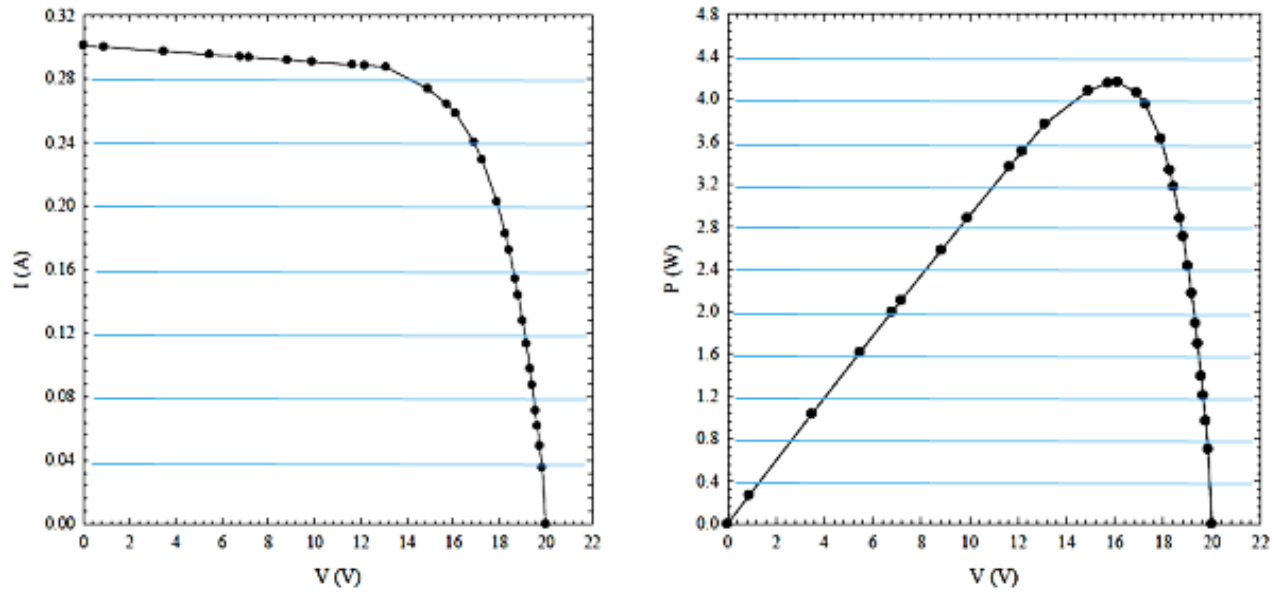

Figure 7. I-V and P-V characteristic curves of m-Si PV module from the fifth test: $G=475 \mathrm{~W} / \mathrm{m}^{2}, T_{c}=27.5^{\circ} \mathrm{C}$, $T_{a}=22.4^{\circ} \mathrm{C}$ and $\phi=\% 58.8$.

The results of the second test are shown in Figure 4. For the second test, solar intensity is measured to be $430 \mathrm{~W} / \mathrm{m}^{2}$. Cell temperature and ambient temperature are determined to be 24.6 and $20.3{ }^{\circ} \mathrm{C}$, respectively. Relative humidity is found to be $64.4 \%$. The results of the third test are given in Figure 5 . For the third test, solar intensity is measured to be $432 \mathrm{~W} / \mathrm{m}^{2}$. Cell temperature and ambient temperature are determined to be 25.7 and $19.8{ }^{\circ} \mathrm{C}$, respectively. Relative humidity is found to be $63.5 \%$. The results of the fourth test are illustrated in Figure 6. For the fourth test, solar intensity is measured to be $450 \mathrm{~W} / \mathrm{m}^{2}$. Cell temperature and ambient temperature are determined to be 36.1 and $24.3{ }^{\circ} \mathrm{C}$, respectively. Relative humidity is found to be $57.9 \%$. The results of the fifth test are shown in Figure 7. For the fifth test, solar intensity is measured to be $475 \mathrm{~W} / \mathrm{m}^{2}$. Cell temperature and ambient temperature are determined to be 27.5 and $22.4{ }^{\circ} \mathrm{C}$, respectively. Relative humidity is found to be $58.8 \%$. According to the results achieved from the independent tests, short circuit current is plotted as a function of solar intensity as shown in Figure 8. It is observed from the findings that the linearity between the incoming solar radiation and short circuit current is maintained despite the noticeable variation in the relative humidity values among the tests. In this respect, it is concluded that relative humidity has no or insignificant influence on current parameters of m-Si PV module. 


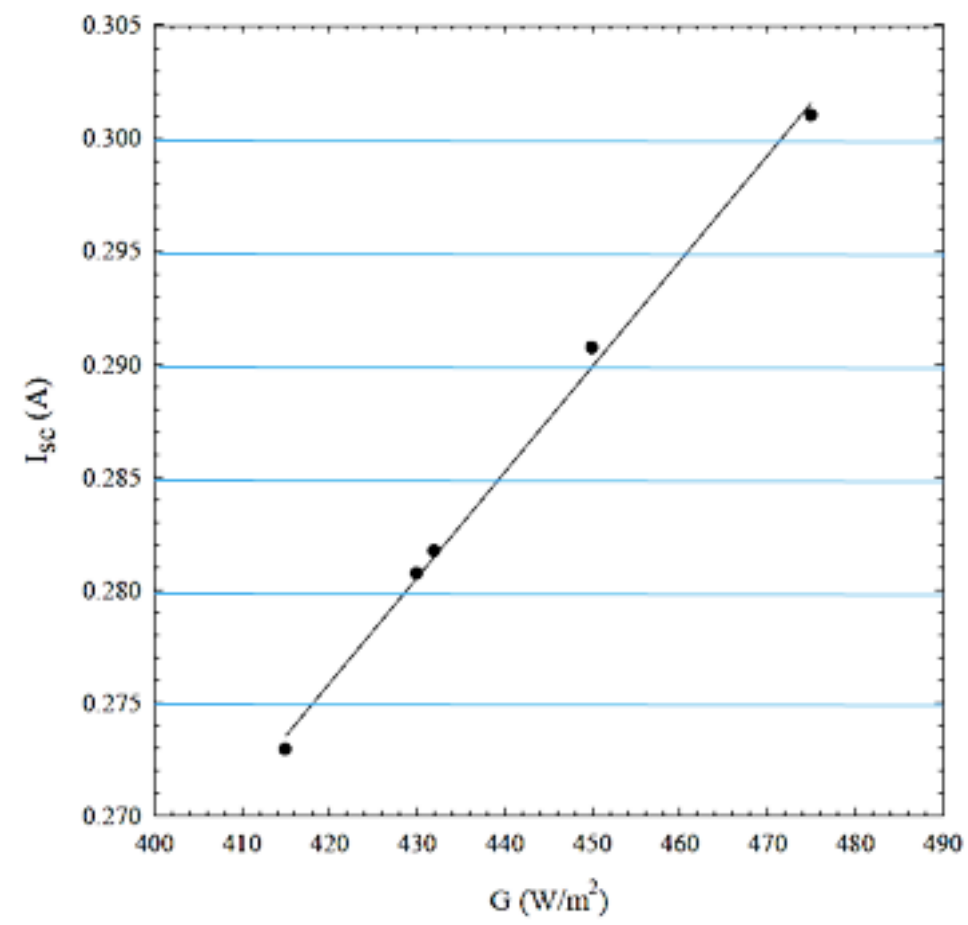

Figure 8. Short circuit current of m-Si PV module as a function of solar intensity through the tests conducted for various relative humidity values $(\phi=\% 61.4, \% 64.4, \% 63.5, \% 57.9$ and \%58.8).

Similar to the methodology applied to m-Si PV module, the independent tests are repeated for $\mathrm{p}-\mathrm{Si} \mathrm{PV}$ module. For p-Si PV module; six independent tests are conducted for six different test days with different climatic conditions. Current-voltage and power-voltage characteristic curves are obtained for each test. The results of the first test are depicted in Figure 9. For the first test, solar intensity is measured to be $257 \mathrm{~W} / \mathrm{m}^{2}$. Cell temperature and ambient temperature are determined to be 28.5 and $25.9^{\circ} \mathrm{C}$, respectively. Relative humidity is found to be $56.4 \%$.
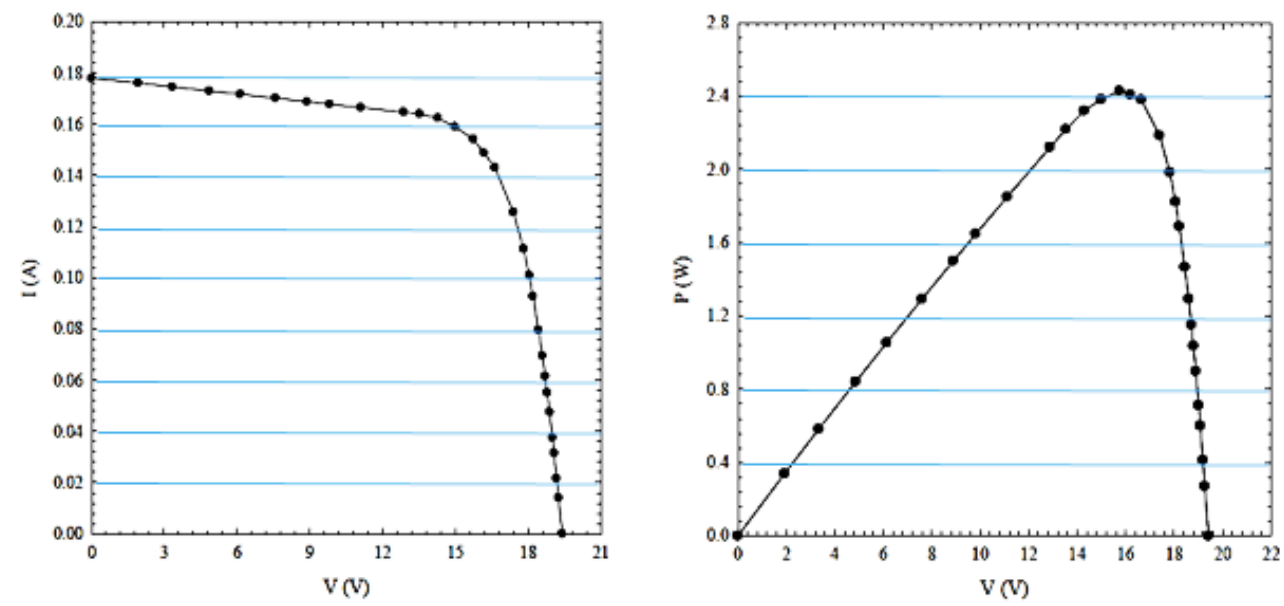

Figure 9. I-V and P-V characteristic curves of p-Si PV module from the first test: $G=257 \mathrm{~W} / \mathrm{m}^{2}, T_{c}=28.5^{\circ} \mathrm{C}$, $T_{a}=25.9^{\circ} \mathrm{C}$ and $\phi=\% 56.4$. 

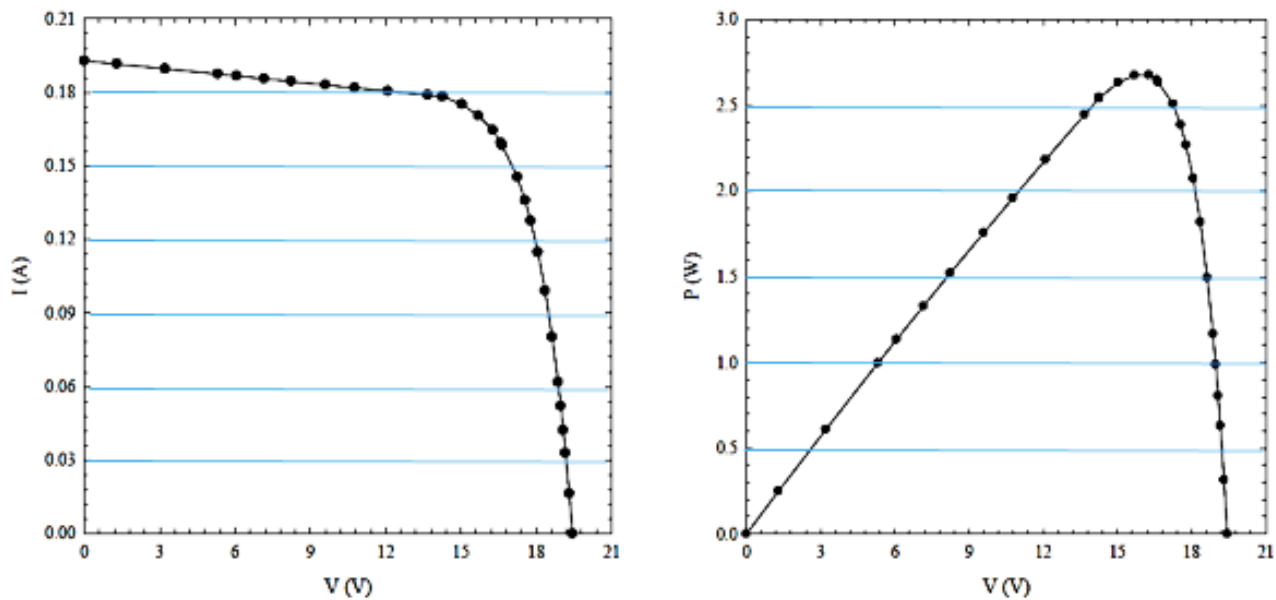

Figure 10. I-V and P-V characteristic curves of $p$-Si PV module from the second test: $G=270 \mathrm{~W} / \mathrm{m}^{2}, T_{c}=$ $27.1^{\circ} \mathrm{C}, T_{a}=25.2^{\circ} \mathrm{C}$ and $\phi=\% 56.3$.
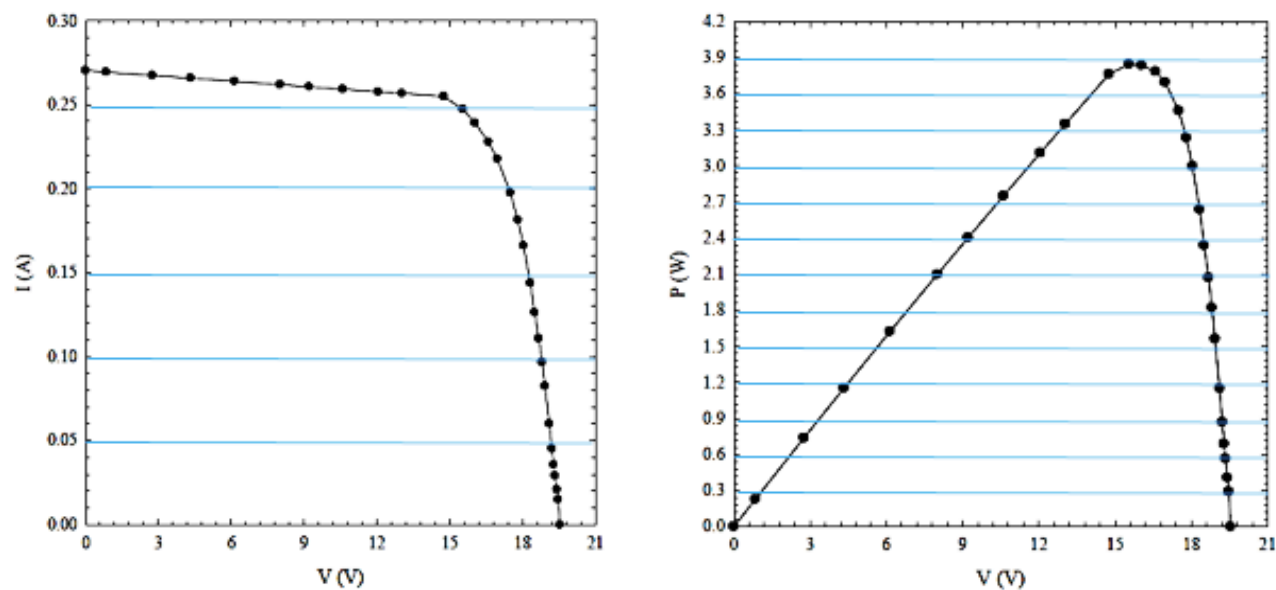

Figure 11. $I$-V and P-V characteristic curves of p-Si PV module from the third test: $G=427 \mathrm{~W} / \mathrm{m}^{2}, T_{c}=38.9^{\circ} \mathrm{C}$, $T_{a}=22.0^{\circ} \mathrm{C}$ and $\phi=\% 58.7$.
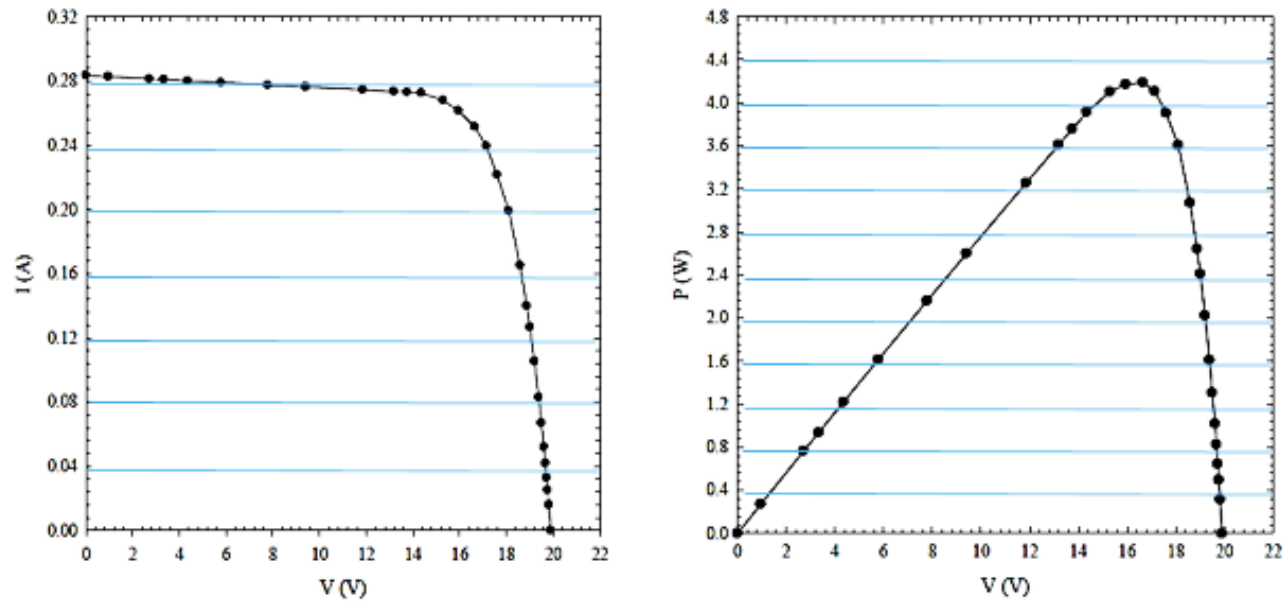

Figure 12. I-V and P-V characteristic curves of p-Si PV module from the fourth test: $G=446 \mathrm{~W} / \mathrm{m}^{2}, T_{c}=21.2$ ${ }^{\circ} \mathrm{C}, T_{a}=19.9^{\circ} \mathrm{C}$ and $\phi=\% 62.7$. 

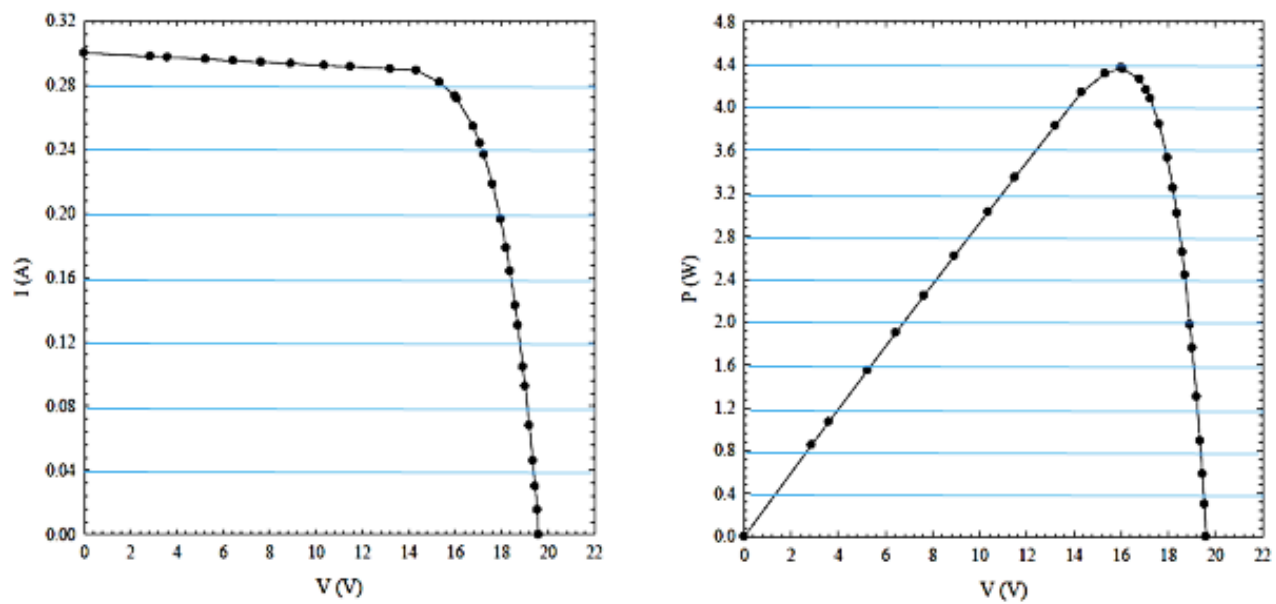

Figure 13. I-V and P-V characteristic curves of p-Si PV module from the fifth test: $G=469 \mathrm{~W} / \mathrm{m}^{2}, T_{c}=33.1^{\circ} \mathrm{C}$, $T_{a}=21.0^{\circ} \mathrm{C}$ and $\phi=\% 63.1$.

The results of the second test are depicted in Figure 10. For the second test, solar intensity is measured to be $270 \mathrm{~W} / \mathrm{m}^{2}$. Cell temperature and ambient temperature are determined to be 27.1 and $25.2{ }^{\circ} \mathrm{C}$, respectively. Relative humidity is found to be $56.3 \%$. The results of the third test are given in Figure 11. For the third test, solar intensity is measured to be $427 \mathrm{~W} / \mathrm{m}^{2}$. Cell temperature and ambient temperature are determined to be 38.9 and $22.0{ }^{\circ} \mathrm{C}$, respectively. Relative humidity is found to be $58.7 \%$. The results of the fourth test are shown in Figure 12. For the fourth test, solar intensity is measured to be $446 \mathrm{~W} / \mathrm{m}^{2}$. Cell temperature and ambient temperature are determined to be 21.2 and $19.9{ }^{\circ} \mathrm{C}$, respectively. Relative humidity is found to be $62.7 \%$. The results of the fifth test are depicted in Figure 13. For the fifth test, solar intensity is measured to be $469 \mathrm{~W} / \mathrm{m}^{2}$. Cell temperature and ambient temperature are determined to be 33.1 and $21.0{ }^{\circ} \mathrm{C}$, respectively. Relative humidity is found to be $63.1 \%$.
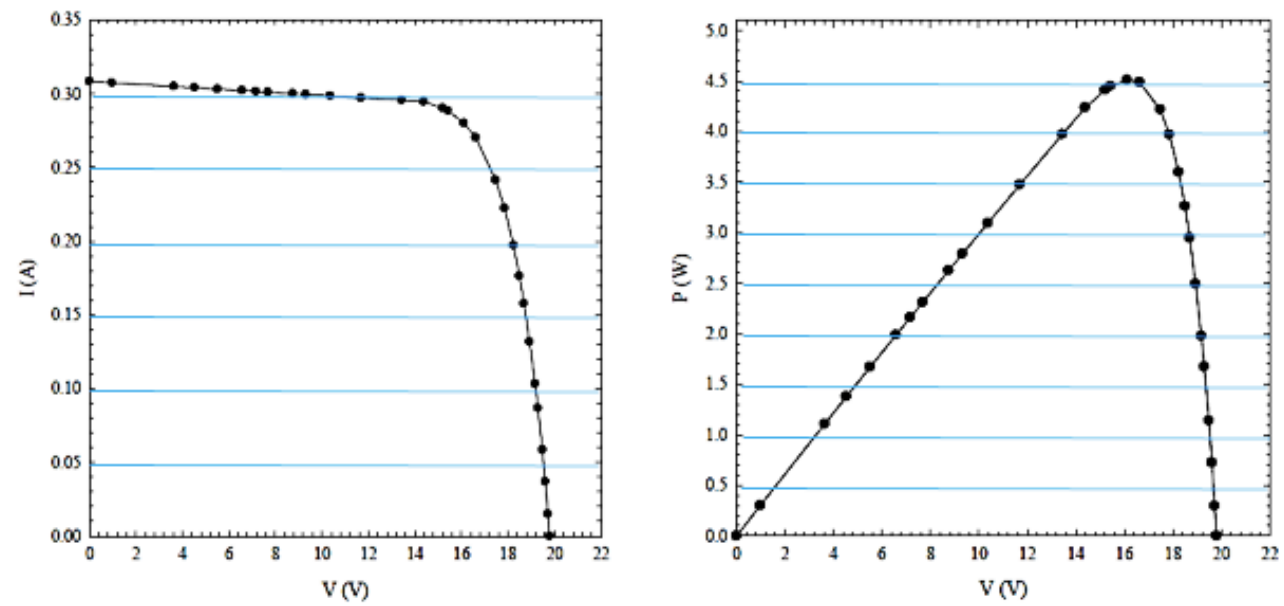

Figure 14. I-V and P-V characteristic curves of p-Si PV module from the sixth test: $G=482 \mathrm{~W} / \mathrm{m}^{2}, T_{c}=35.7^{\circ} \mathrm{C}$, $T_{a}=22.4^{\circ} \mathrm{C}$ and $\phi=\% 57.9$.

The results of the sixth test are depicted in Figure 14. For the sixth test, solar intensity is measured to be $482 \mathrm{~W} / \mathrm{m}^{2}$. Cell temperature and ambient temperature are determined to be 35.7 and $22.4{ }^{\circ} \mathrm{C}$, respectively. Relative humidity is found to be $57.9 \%$. Through the results obtained from the independent tests, short circuit current is plotted as a function of solar intensity as shown in Figure 15. It is observed from the findings that the linearity between the incoming solar radiation and short circuit current is maintained like in the case of $\mathrm{m}$-Si PV module although there is a notable variation in the 
relative humidity values among the tests. In this respect, it is concluded that relative humidity has no or insignificant influence on current parameters of p-Si PV module similar to m-Si PV module.

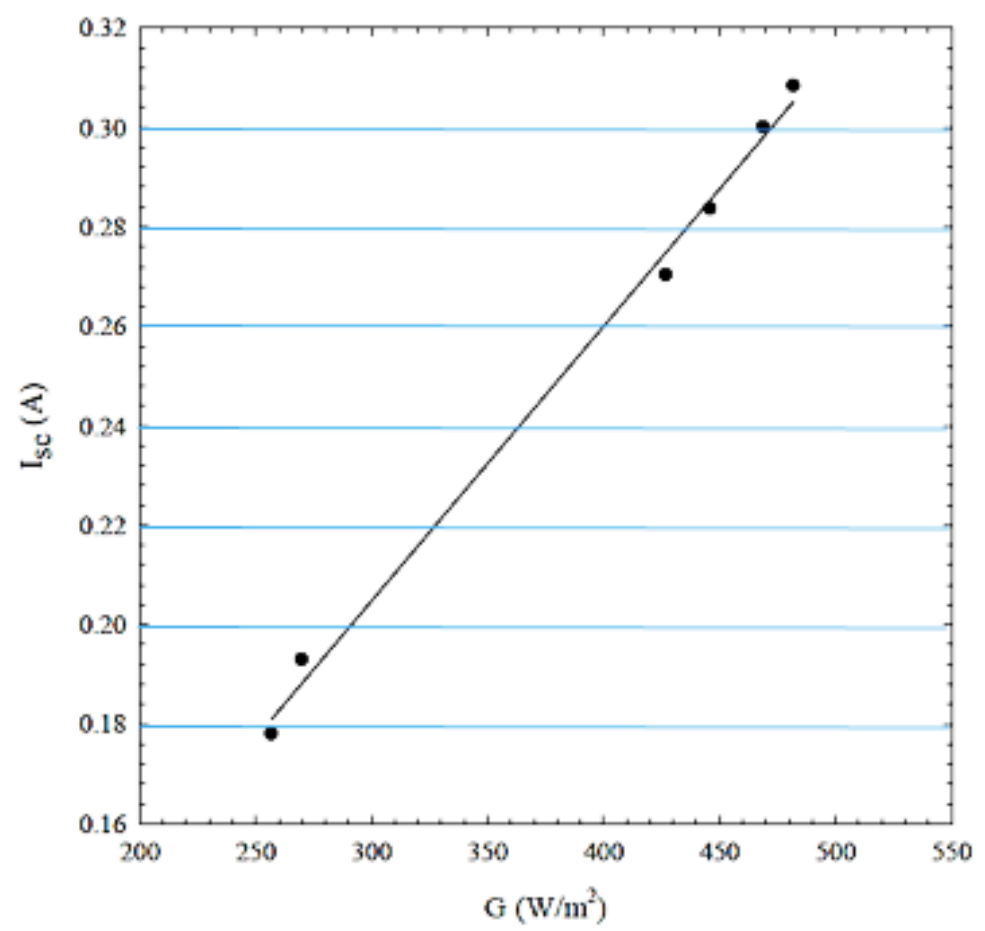

Figure 15. Short circuit current of p-Si PV module as a function of solar intensity through the tests conducted for various relative humidity values ( $\phi=\% 56.4, \% 56.3, \% 58.7, \% 62.7, \% 63.1$ and \%57.9).

Overall, it needs to be noted that the impact of relative humidity on electrical performance parameters of $\mathrm{m}-\mathrm{Si}$ and $\mathrm{p}-\mathrm{Si} \mathrm{PV}$ modules is found to be insignificant. There are some works in literature which support this finding. On the other hand, some works claim that PV modules perform better at lower relative humidity levels. For instance, Rahman et al. [35] assert that power output of a PV module is measured to be $25.31 \mathrm{~W}$ at $\phi=\% 40$ whereas it is found to be $22.15 \mathrm{~W}$ at $\phi=\% 60$. The electrical performance tests conducted under solar simulators might result inaccurate data due to the difference in spectrum data. Artificial solar simulators usually produce waste heat to the test room which directly affect the operating cell temperature thus the power output and efficiency figures. Therefore, outdoor tests are always reliable for such attempts. By the way, a wide range of relative humidity can be studied in the further works or the tests can be repeated under real solar simulators which are integrated with environmental chambers for a much more accurate and scientific assessment. Even so, the results are coherent enough for a general evaluation of the impact of relative humidity on current parameters of PV modules.

\section{CONCLUSIONS}

In this research, the impact of relative humidity on current parameters of $\mathrm{m}-\mathrm{Si}$ and $\mathrm{p}$-Si PV modules is investigated. An experimental methodology is considered in the study, and several independent tests are carried out to evaluate the potential influence of moisture content of air on the incoming solar radiation, thus on the current parameters such as photocurrent and short circuit current. Currentvoltage (I-V) and power-voltage (P-V) characteristics are determined simultaneously for each PV module, and the relationship between the short circuit current $\left(\mathrm{I}_{\mathrm{sc}}\right)$ and the relative humidity is 
assessed. During the tests, PV cell temperature of $\mathrm{m}-\mathrm{Si}$ and $\mathrm{p}$-Si sample is observed to be in the range of 22.9-36.1 and 21.2-38.9 ${ }^{\circ} \mathrm{C}$, respectively. The tests repeated for low and moderate solar intensity levels $\left(257-482 \mathrm{~W} / \mathrm{m}^{2}\right)$ indicate that the linear relationship between $\mathrm{G}$ and $\mathrm{I}_{\mathrm{sc}}$ is maintained for different humidity levels. In this respect, the influence of humidity level on current parameters of PV cells is found to be insignificant. Overall, it can be easily concluded that the findings of the research are of vital importance for the further feasibility works on PV systems which are scheduled to be built in humid climatic conditions. Contradictions in the previous literature regarding the potential impact of relative humidity on performance figures of PV modules are resolved in this respect.

\section{Acknowledgements}

We are grateful to TUBITAK (The Scientific and Technological Research Council of Turkey) as they fund this research through the project entitled "Thermodynamic analysis of the effectiveness of different types of PV modules for wet conditions" with the grant number 107M642.

\section{REFERENCES}

[1] Cuce E. Development of innovative window and fabric technologies for low-carbon buildings. Ph.D. Thesis, The University of Nottingham, 2014.

[2] Cuce E, Cuce PM, Bali T. An experimental analysis of illumination intensity and temperature dependency of photovoltaic cell parameters. Applied Energy 2013; 111: 374-382.

[3] Cuce E, Cuce PM. Improving thermodynamic performance parameters of silicon photovoltaic cells via air cooling. International Journal of Ambient Energy 2014; 35(4): 193-199.

[4] Cuce E, Oztekin EK, Cuce PM. Hybrid photovoltaic/thermal (HPV/T) systems: From theory to applications. Energy Research Journal 2018; (In Press).

[5] Cuce PM, Cuce E. A novel model of photovoltaic modules for parameter estimation and thermodynamic assessment. International Journal of Low-Carbon Technologies 2012; 7(2): 159-165.

[6] Cuce E, Cuce PM, Karakas IH, Bali T. An accurate model for photovoltaic (PV) modules to determine electrical characteristics and thermodynamic performance parameters. Energy Conversion and Management 2017; 146: 205-216.

[7] Daneshazarian R, Cuce E, Cuce PM, Sher F. Concentrating photovoltaic thermal (CPVT) collectors and systems: A comprehensive review. Renewable and Sustainable Energy Reviews 2018; 81(1): 473-492.

[8] Riffat SB, Cuce E. A review on hybrid photovoltaic/thermal collectors and systems. International Journal of Low-Carbon Technologies 2011; 6(3): 212-241.

[9] Riffat SB, Cuce E. A review on performance analysis of photovoltaic/thermal collectors. Tenth International Conference on Sustainable Energy Technologies. 4-7 September 2011, Istanbul, Turkey.

[10] Cuce E, Bali T. Variation of cell parameters of a p-Si PV cell with different solar irradiances and cell temperatures in humid climates. Fourth International Exergy, Energy and Environment Symposium. 1923 April 2009, Sharjah, United Arab Emirates.

[11] Cuce E, Bali T. A comparison of energy and power conversion efficiencies of m-Si and p-Si PV cells in Trabzon. Fifth International Advanced Technologies Symposium. 13-15 May 2009, Karabuk, Turkey.

[12] Cuce E, Bali T. Improving performance parameters of silicon solar cells using air cooling. Fifth International Ege Energy Symposium and Exhibition. 27-30 June 2010, Denizli, Turkey.

[13] Cuce PM, Cuce E. Passive cooling of building-integrated photovoltaics (BIPVs) for better electrical performance. MEGS IV Annual Conference, Public Engagement with Energy. 12-13 September 2013, Loughborough, United Kingdom.

[14] Cuce E, Cuce PM. Tilt angle optimization of building-integrated photovoltaics (BIPVs) for cooler operating temperatures. MEGS IV Annual Conference, Public Engagement with Energy. 12-13 September 2013, Loughborough, United Kingdom.

[15] Daneshazarian R, Cuce E, Cuce PM. An overview of concentrating photovoltaic thermal (CPVT) collectors. Energy Research Journal 2017; 8(1): 11-21.

[16] Cuce E, Bali T, Sekucoglu SA. Effects of passive cooling on performance of silicon photovoltaic cells. International Journal of Low-Carbon Technologies 2011; 6(4): 299-308. 
[17] Sauer KJ, Roessler T, Hansen CW. Modeling the irradiance and temperature dependence of photovoltaic modules in PVsyst. IEEE Journal of Photovoltaics 2015; 5(1): 152-158.

[18] Cuce E. Thermodynamic analysis of the effectiveness of different types of PV modules for wet conditions. M.Sc. Thesis, Karadeniz Technical University, 2009.

[19] Orioli A, Gangi AD. A procedure to calculate the five-parameter model of crystalline silicon photovoltaic modules on the basis of the tabular performance data. Applied Energy 2013; 102:1160-1177.

[20] Ciulla G, Brano VL, Di Dio V, Cipriani G. A comparison of different one-diode models for the representation of I-V characteristic of a PV cell. Renewable and Sustainable Energy Reviews 2014; 32:684-696.

[21] Bouzidi K, Chegaar M, Bouhemadou A. Solar cells parameters evaluation considering the series and shunt resistance. Solar Energy Materials and Solar Cells 2007; 91: 1647-1651.

[22] Chegaar M, Ouennoughi Z, Guechi F. Extraction DC parameters of solar cells under illumination. Vacuum 2004; 75: 367-372.

[23] Chegaar M, Ouennoughi Z, Hoffmann A. A new method for evaluating illuminated solar cell parameters. Solid-State Electronics 2001; 45: 293-296.

[24] Chegaar M, Azzouzi G, Mialhe, P. Simple Parameter extraction method for illuminated solar cells. SolidState Electronics 2006; 50: 1234-1237.

[25] Adawi MK, Nuaim IA. A method to determine the solar cell series resistance from a single $I-V$ characteristic curve considering its shunt resistance. Vacuum 2002; 64: 33-36.

[26] Radziemska E, Klugmann E. Thermally affected parameters of the current-voltage characteristics of silicon photocell. Energy Conversion and Management 2002; 43: 1889-2000.

[27] Jordehi AR. Enhanced leader particle swarm optimisation (ELPSO): An efficient algorithm for parameter estimation of photovoltaic (PV) cells and modules. Solar Energy 2018; 159:78-87.

[28] Bastidas-Rodriguez JD, Petrone G, Ramos-Paja CA, Spagnuolo G. A genetic algorithm for identifying the single diode model parameters of a photovoltaic panel. Mathematics and Computers in Simulation 2017; 131:38-54.

[29] Oliva D, El Aziz MA, Hassanien AE. Parameter estimation of photovoltaic cells using an improved chaotic whale optimization algorithm. Applied Energy 2017; 200:141-154.

[30] Chen X, Xu B, Mei C, Ding Y, Li K. Teaching-learning-based artificial bee colony for solar photovoltaic parameter estimation. Applied Energy 2018; 212:1578-1588.

[31] Mekhilef S, Saidur R, Kamalisarvestani M. Effect of dust, humidity and air velocity on efficiency of photovoltaic cells. Renewable and Sustainable Energy Reviews 2012; 16(5):2920-2925.

[32] Cuce E. Toward thermal superinsulation technologies in buildings: Latest developments in glazing and building fabric. LAP Lambert Academic Publishing, Saarbrücken, Germany, 2015.

[33] Gwandu BA, Creasey DJ. Humidity: a factor in the appropriate positioning of a photovoltaic power station. Renewable Energy 1995; 6(3):313-316.

[34] Holman JP. Experimental Methods for Engineers, 7th edition, McGraw-Hill Higher Education, 2000.

[35] Rahman MM, Hasanuzzaman M, Rahim NA. Effects of various parameters on PV-module power and efficiency. Energy Conversion and Management 2015; 103: 348-358. 